\title{
ALBION
}

\section{Contents of Volume 8}

\section{Number 1, Spring, 1976}

1 The Tithe Heresy of Friar William Russell Craig A. Robertson

17 The Nature of Opposition in the House of Lords in the Early Seventeenth Century

Jess Stoddart Flemion

35 "Twenty-Four Arguments": Sir Robert Cotton Confronts the Catholics and the Church of England

Marc L. Schwarz

50 The Regimental Courts Martial in the Eighteenth Century

British Army

Arthur N. Gilbert

67 The Myth of William Morris

Martin J. Weiner

83 Historians and the Great Crisis of 1903

Alfred Gollin

98 Reports of Proceedings

Number 2, Summer, 1976

107 Stubbs, Shakespeare, and Recent Historians of Richard II John M. Theilmann

125 Growing Old in Seventeenth Century England Steven $R$. Smith

142 The Mid-Nineteenth Century Electoral Structure Richard W. Davis

154 A Matter of Policy: The Lessons of Recent British Race Relations Legislation John Carson

178 Reports of Proceedings 
203 The Crown and the Aristocracy in England, 1450-1509 J.R. Lander

219 The French Huguenots and the Civil List, 1696-1727: A Study of Alien Assimilation in England

Roy A. Sundstrom

236 "An Handful of Violent People": The Nature of the Foxite Opposition, 1794-1801

Richard E. Willis

255 Separating the Sheep from the Goats: Victorian Didactic Hymns

Susan Smith Tamke

274 The Political Aspects of Women's Suffrage During the First World War John D. Fair

Note:

296 British Cabinet Office Records on the Second World War W. David Rozkuszka

$300 \quad$ Books Received

Number 4, Winter 1976

301 The Anglo-Papal Bargain of 1125:

The Legatine Mission of John of Crema

Sandy Burton Hicks

311 The Basis of the Lords' Decision in the Trial of Strafford:

Contravention of the Two Witness Rule John H. Timmis III

320 Sir Arthur Hesilrige: The Forgotten Knight of the Long Parliament Hugh $R$. Engstrom, Jr.

333 The Whig Prince: Prince Rupert and the Court vs. Country Factions During the Reign of Charles II Leslie Chree O'Malley

351 Lord Durham, the Whigs and Canada, 1838:

The Background to Durham's Return

I.D.C.Newbould

375 Reports of Proceedings

390 Index to Volume 8 


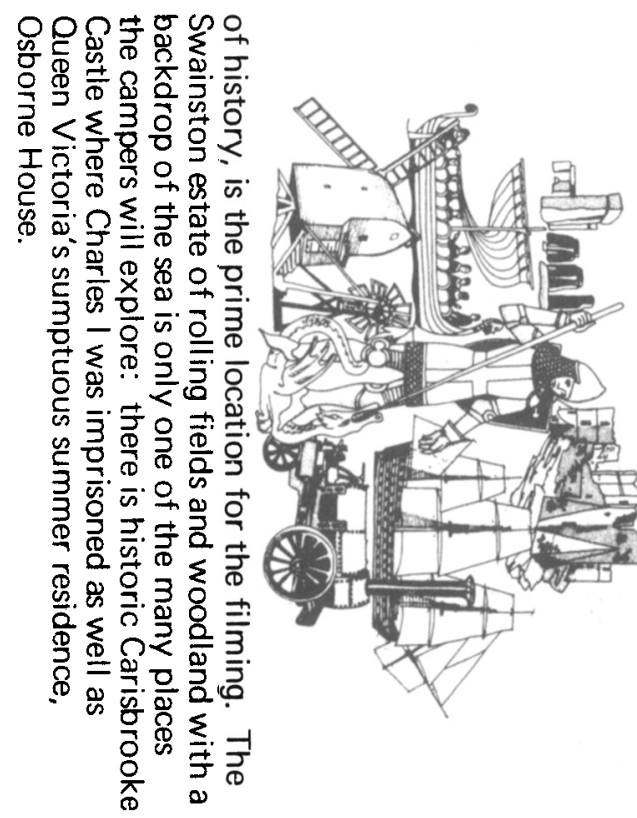

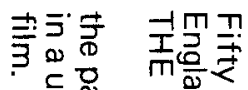
>흘. 을

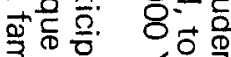

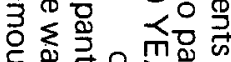

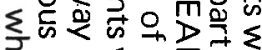

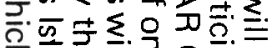

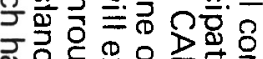

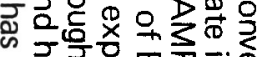

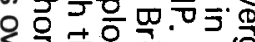

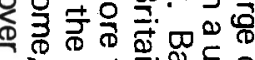

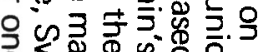

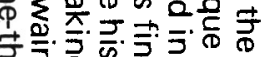

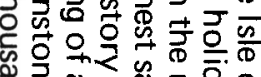

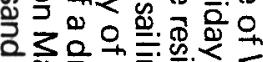
$<$ 可

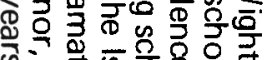

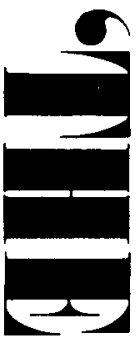

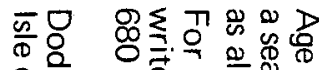

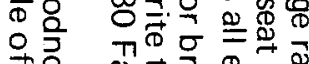

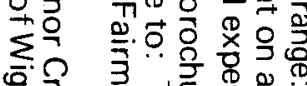
을 色

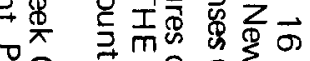

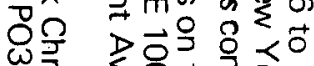

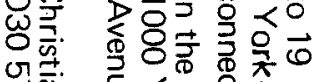

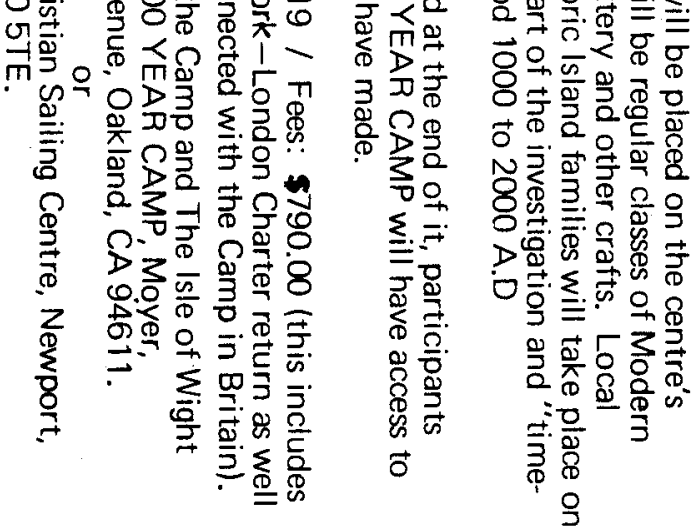

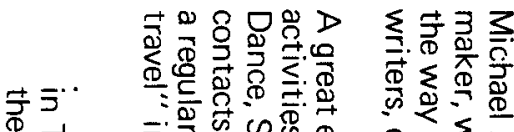
거.

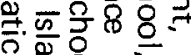
商 $\frac{8}{4}$

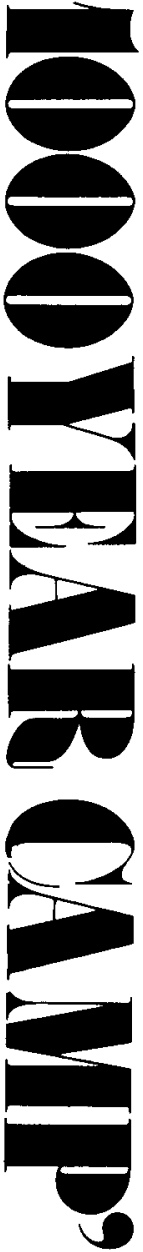


